\title{
GLOBALISATION OF COMMERCIAL THEME PARKS Case: the Walt Disney Company
}

\author{
Patrick De Groote
}

\author{
Universiteit Hasselt \& KULeuven
}

\begin{abstract}
In this contribution we focus on the globalisation of commercial theme parks with Walt Disney Company as the best known case study. After definitions and historical background of theme parks, we analyse the visitors key factors. For the Walt Disney Cie we start with some historical facts, we set up a SWOT-analysis and focus then on Euro Disneyland Paris, the biggest theme park of Europe.
\end{abstract}

Key words: Theme Parks, Walt Disney Company, Euro Disneyland

\section{Introduction}

The Economics Research Associates (ERA) defines a theme park as "A gated attraction that contains rides and/or shows in a themed environment, offers a pay-one-price ticket for its guests and attracts at least 500,000 annual visits" (ERA, 2007).

A more detailed description for theme parks is given by Philip L.Pearce (in Jafar Jafari, 2000, p.124-5): "Theme parks are capital intensive, highly developed, self-contained recreational spaces which invariably charge admission. The entertainment, rides, speciality foods and park buildings are usually organised around themes or unifying ideas such as a specific period in history or a particular geographic region. These themes are crucial to the operation of the parks as they create a feeling of involvement in a setting which is in stark contrast to daily life. A distinction can be drawn between the commercial theme parks, which are well describes by the theming and entertainment elements mentioned, and outdoor museums or historic theme parks, which may be less commercial in emphasis and have goals in heritage preservation and public education".

Theme park is the basic term for a compilation of rides and other amusement attractions pull together for the purpose of entertaining a group of people. The theme park is more complex than a simple city park or recreational area. This park is a type of amusement park, built around one or more topics (i.e. American Far West theme or Pirates of the Carribean).Theme parks developed in Europe from leisure gardens. The oldest amusement park of the world (since 1583 ) is "Bakken" at Klampenborg (north of Copenhagen) which is still in operation. In the USA, world fairs and expos induced a real expansion of the amusement park business. (www.weitzlux.com)

A theme park includes a combination of attractions which can be classified into several categories: thrill rides, roller coasters, family rides, water attractions or (indoor) dark rides. Major part of theme parks' revenue comes from entrance fees. Standard admission for a pay-one-price park is (normally) more than $\$ 30$ with discounts for children and senior residents. Most theme parks also charge for car parking and ticket prices do not include food, which can be very costly. Almost all amusement parks operate using one of two admission principles: Pay as you go (= pay for rides individually) or Pay one price (= one big admission charge, for (almost) all of the attractions).

\subsection{History of theme parks}

The Feast of St.Bartholomew (since 1133 yearly hold in England), is the father for amusement and theme parks. Theme parks became popular at the beginning of the Industrial Revolution, such as the Vauxhall Gardens (1661) in London, or Prater (1766) in Vienna.

Another type of fair is the World Exhibition or Expo. World Expos started in 1851 with the Crystal Palace in London's Hyde Park. The World's Columbian Exposition in 1893 in Chicago is an early pioneer of the modern theme park and introduced the Ferris Wheel. (P. De Groote, 2006, p.38-39).

In 1894, Paul Boynton Water Chutes opened the world's first new amusement park and charged entrance for the rides. In 1895, he also built a park at Coney Island (New York), which is still very popular. By the early 1900 s, there were hundreds of theme parks worldwide, and it was the period of the "golden age" until the late 1920s, mainly due to the increase of income and the decrease of labour time. In the 1930s during the Great Depression and World War II the decline of the theme parks was a fact. After the WWII the influence of television was negative and families visited theme parks seldom. (www.ultimaterollercoaster.com). The historical overview and location of the main European theme parks is showed in figure 1. The pioneers are situated in the period before 1955 . 


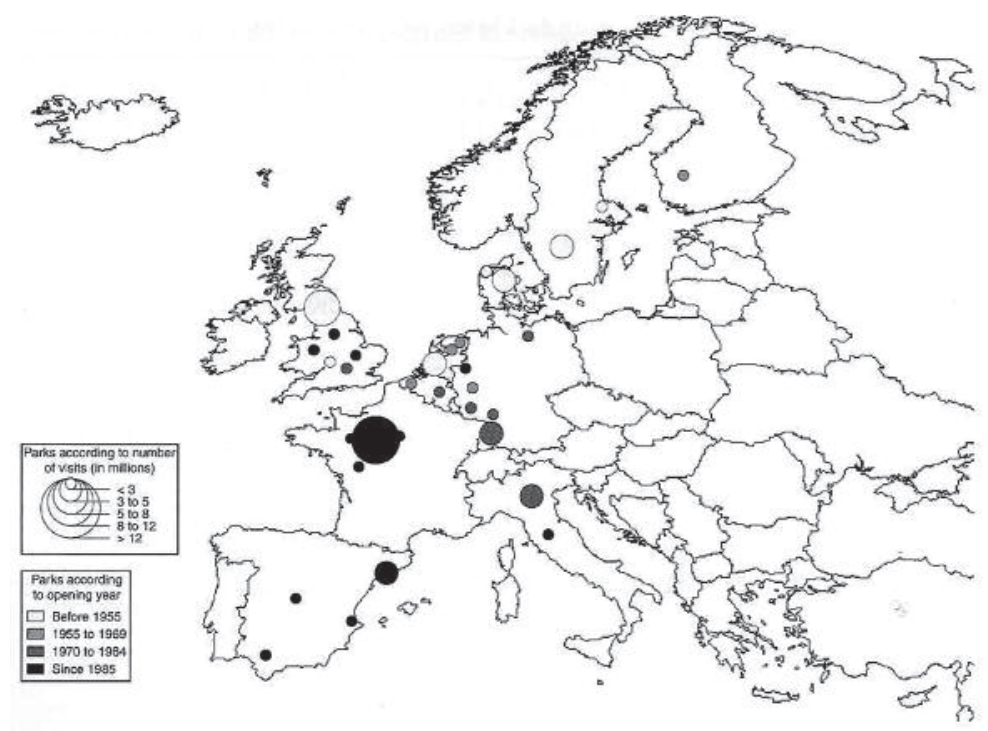

Figure 1: History and location of the main theme parks in Europe Source: Clave A., 2007, p. 68

Universal Studios illustrates the progress of an attraction (= originally train ride tour of the studios in Hollywood) into a complete theme park. In 1990, Universal Studios Florida in Orlando was opened. Universal Studios is now the secondlargest theme park group in the world, only competed in size with Disney itself. During the 1970s, the theme park business initiated to mature as a mixture of refreshed traditional

Table 1. Top 10 Amusement/Theme Park Groups worldwide (2007)

\begin{tabular}{clr} 
Rank & Theme Park Attraction Chain & $\begin{array}{r}2007 \text { Attendance } \\
\text { (millions) }\end{array}$ \\
\hline 1 & WALT DISNEY ATTRACTIONS & 116.5 \\
2 & MERLIN ENTERTAINMENT GROUP & 32.1 \\
\hline 3 & UNIVERSAL STUDIOS RECREATION GROUP & 26.4 \\
\hline 4 & SIX FLAGS INC. & 24.9 \\
\hline 5 & BUSCH ENTERTAINMENT & 22.3 \\
\hline 6 & CEDAR FAIR ENTERTAINMENT COMPANY & 22.1 \\
\hline 7 & PARQUES REUNIDOS & 12.0 \\
\hline 8 & COMPAGNIE DES ALPES (GREVIN) & 9.6 \\
\hline 9 & HERSCHEND FAMILY ENTERTAINMENT & 8.9 \\
10 & EVERLAND & 8.6
\end{tabular}

Source: TEA/ERA, 2008, Theme Park Attraction Attendance Report 2007., p.VI

Table 2. Theme parks of the Walt Disney Group (2006)

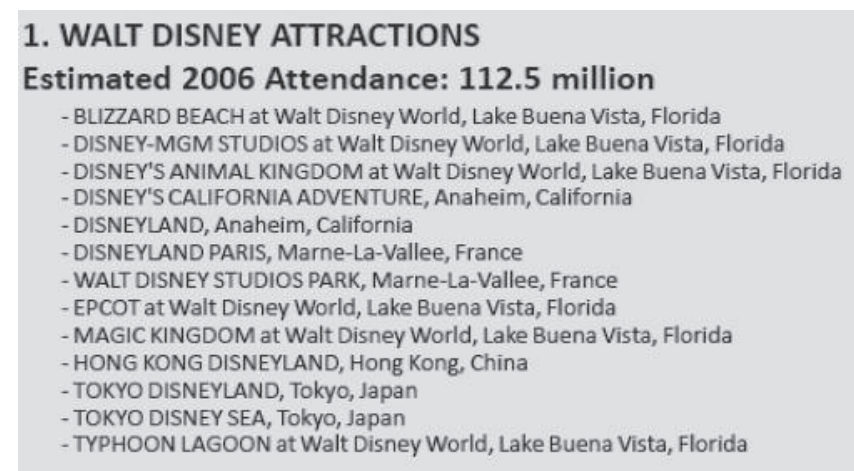

Source: ERA, 2007, p. 10 amusement parks and new projects financed by bigger firms emerged. Most of today's major theme parks were built in the 1970s and belongs now to some major globalised groups (table 1), with Walt Disney (table 2) in the USA as the biggest, and for Europe: Merlin Entertainments (GB), Euro Disney SCA (F), Parques Reunidos (E) and Compagnie des Alpes (Grevin)(F).

\subsection{Visitors key factors}

Products, experiences, and people are the lifeblood of the theme parks. Managers must take into consideration a lot of influencing factors. The origins of the International Association of Amusement Parks and Attractions (IAAPA, www.iaapa.org) goes back to 1918, as a USA association (formerly the National Association of Amusement Parks). Now it is the world's premier amusement association with headquarters in Alexandria (USA) and the European one in Brussels.

Based on the survey of May 2007 (www.iaapa.org) we see that adults with higher incomes (figure 2) are more visiting theme parks. An yearly average of $80 \%$ adults would visit a park again in the next year. Repeat visitors are of significant importance for the continuous success of theme parks. For the adults, spending time (figure 3) with family and friends was their preferred characteristic of a visit theme park $(43 \%)$. Second were rides ( $24 \%)$, shows $(9 \%)$, games $(5 \%)$,

Diagram 1B: Respondents who visited an amusement/theme park in past 12 months, by annual income (May 2007)

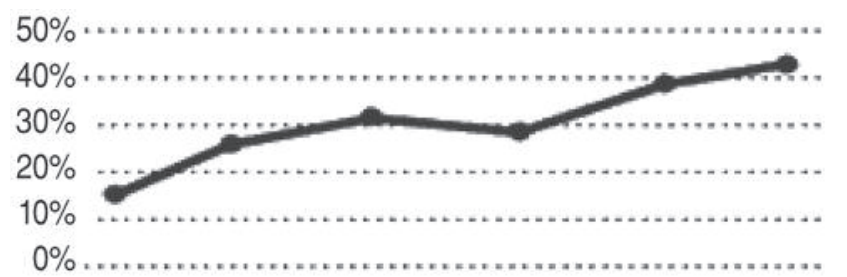

$<$ <20K \$20-29.9K \$30-39.9K \$40-49.9K \$50-74.9K \$75K>

Figure 2. Relationship between visitors of a theme park and income (May 2007) Source: www.iaapa.org

Diagram 4: Favorite thing about visiting an amusement/theme park (May 2007)

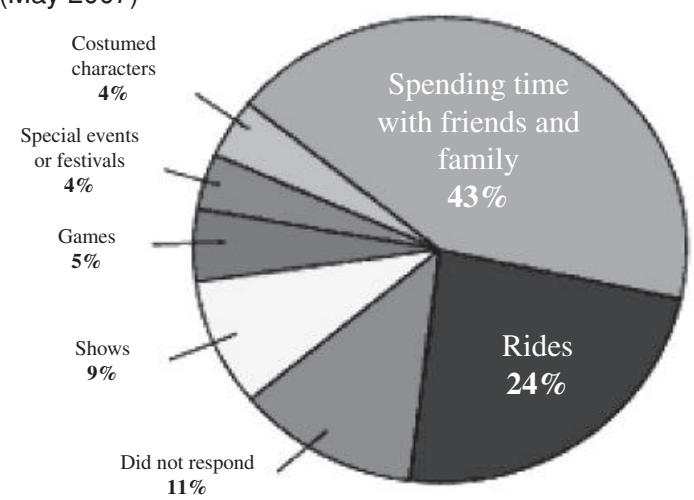

Figure 3. Activities of visitors in a theme park Source: www.iaapa.org 
and both costumed characters and special events (4\%). The percentage of adult whose last theme park journey (figure 4) contained an overnight stay has risen slightly during 2005-07 to an average of $33 \%$.

Diagram 5A: Respondents who last amusement/theme park visit included an avernight stay, by age

\section{8-to 24-year-olds 25-34 푸 35-49 50-64}

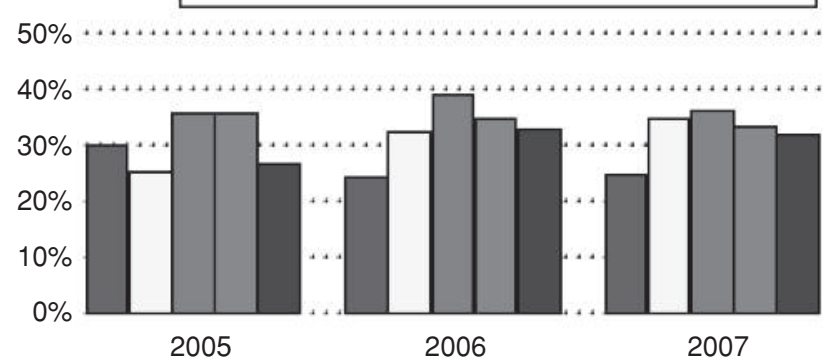

Figure 4. Relationship visitors of theme parks and overnight stays Source: www.iaapa.org

Table 3 shows the total attendance for the world's Top 25 theme parks in 2007. Disney's Magic Kingdom in Orlando was the most world's popular theme park with 17,060,000 guests. Eight of the top 10 parks across the globe were Disney parks. The Latin America market is less expanded compared to North America and Europe because of a difference in income levels. Asia is experiencing stronger expansion, mainly spectacular in China where the middle class is increasing rapidly. Some major attraction plans are in the channel with the region including a Universal Studios

Table 3. Top 20 Theme parks worldwide (2007)

\begin{tabular}{|c|c|c|}
\hline Rank & Park and Location & 2007 Attendance \\
\hline 1 & MAGIC KINGDOM at Wath Disney Wond, Lake Buene Vista, FL, USA & $17,060,000$ \\
\hline 2 & DISNEYLAND, Anahoim, CA, USA & $14,870,000$ \\
\hline 3 & TOKYO DISNEYLAND, Tokyo, Japan & $13,906,000$ \\
\hline 4 & TOKYO DISNEYSEA, Tokyo, Japan & $12,413,000$ \\
\hline 5 & DISNEYLAND PARIS, Marne-La-Vallee, France & $12,000,000$ \\
\hline 6 & EPCOT at Wak Disney World, Leke Buena Vista, FL, USA & $10,930,000$ \\
\hline 7 & DISNEYS HOLLYWOOD STUDIOS at Walt Disney Wond, Lake Buena V & $9,510,000$ \\
\hline 8 & DISNEYS ANIMAL KINGDOM at Wait Disnoy World, Lake Buena Vista, FL & $9,490,000$ \\
\hline 9 & UNIVERSAL STUDIOS JAPAN, Osaka, Japan & $8,713,000$ \\
\hline 10 & EVERLAND, Kyonggi-Do, South Korea & $7,200,000$ \\
\hline 11 & UNIVERSAL STUDIOS at Universat Oriando, Orlando, FL & $6,200,000$ \\
\hline 12 & SEAWORLD FLORIDA, Orlando, FL, USA & $5,800,000$ \\
\hline 13 & DISNEYS CALIFORNIA ADVENTURE, Anahoim, CA, USA & $5,680,000$ \\
\hline 14 & PLEASURE BEACH, 3lackpool, UK & $5,500,000$ \\
\hline 15 & ISLANDS OF ADVENTURE at Unversal Orlando, Orlando, FL, USA & $5,430,000$ \\
\hline 16 & OCEAN PARK, Hong Kong, China & $4,920,000$ \\
\hline 17 & HAKKEIJIMA SEA PARADISE, Yokohama, Japan * & $4,770,000$ \\
\hline 18 & UNIVERSAL STUDIOS HOLLYYWOOD, Universal City, CA USA & $4,700,000$ \\
\hline 19 & BUSCH GARDENS TAMPA BAY, Tampa Bay, FL, USA & $4,400,000$ \\
\hline 20 & SEAWORLD CALIFORNIA, San Diego, CA, USA & $4,260,000$ \\
\hline 21 & HONG KONG DISNEYLAND, Harg Kong, SAR, China & $4,150,000$ \\
\hline 22 & TIVOLI GARDENS, Copenhagen, Denmark & $4,110,000$ \\
\hline 23 & EUROPA-PARK, Rust Gomany & $4,000,000$ \\
\hline 24 & NAGASHIMA SPA LAND, Kuwana, Japan & $3,910,000$ \\
\hline 25 & PORT AVENTURA, Salou, Spain & $3,700,000$ \\
\hline
\end{tabular}

Source: TEA/ERA, 2008, Theme Park Attraction Attendance Report 2007, p.VII theme park in Singapore in 2010. European parks are being well sustained and reloaded by ongoing private investment. (www.themeit.com/attendance_report2007.pdf)

The 2007 total attendance for the Top 20 theme parks in Europe (table 4) was 60.9 million, standing for a growth rate of $3 \%$ compared to 2006 (cf. $2.6 \%$ for Nort America). Table 5 shows the evolution of number of visitors in the European theme parks (1995-2007). European theme parks have a process for expanding the season that has little to do with including infrastructure, such as the Christmas market. Tivoli has been the top player in Europe in successfully expanding its season - with a new Halloween celebration in October. Both events extensively increased the park's attendance and incomes. In general, the European theme parks are relatively stagnant compared to the United States or Asia. The Top 20 have not changed greatly. Geography and strong national character are major aspects. Each country has one big park and one lead market. Apart from Disney, European theme parks are local ones. (www.themeit.com/attendance_report 2007.pdf)

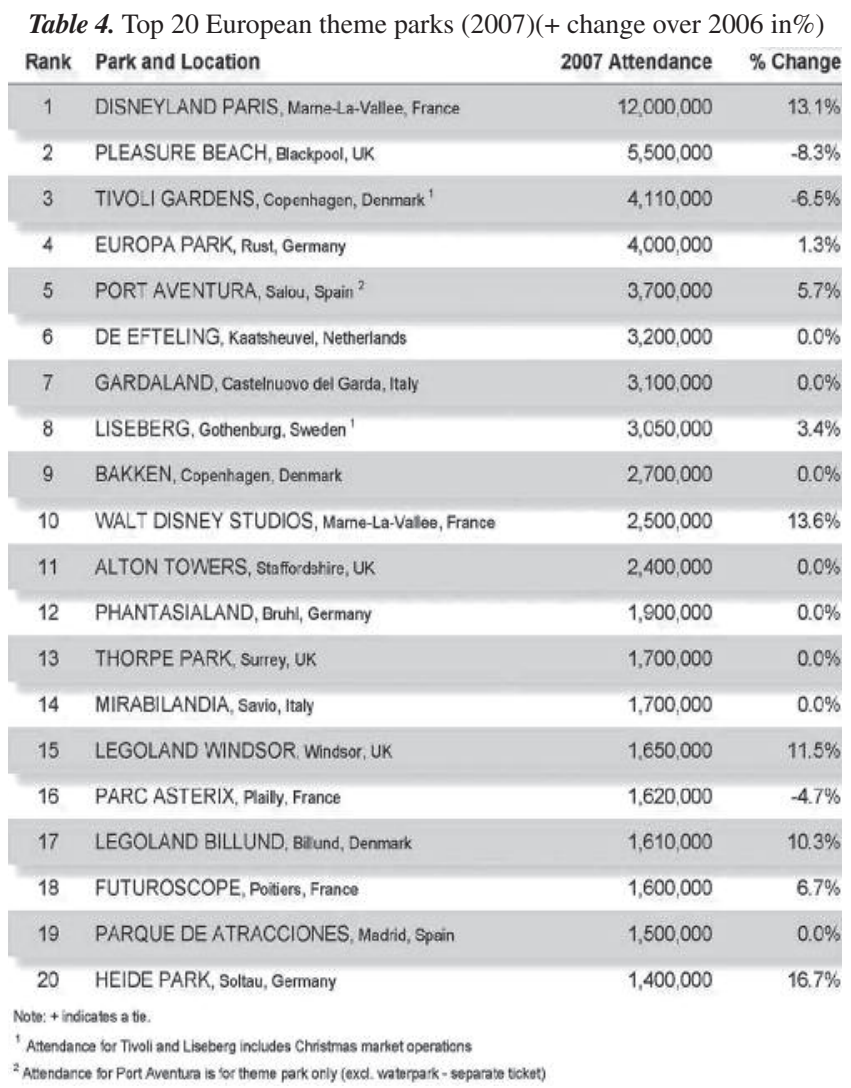

Source: TEA/ERA, Theme Park Attraction Attendance Report, p.XI

\section{The Walt Disney Company}

The Walt Disney Company works as a diversified amusement company worldwide. The corporation's Media Networks sector contains networks of Internet, mobile operations, radio and television. The Walt Disney Company's Parks and Resorts sector holds and controls the Walt Disney 
Table 5. Evolution of number of visitors (in million) in the European theme parks (1995-2007)

\begin{tabular}{|l|r|r|r|r|r|r|r|r|r|r|r|r|r|}
\hline Parknaam & $\mathbf{1 9 9 5}$ & $\mathbf{1 9 9 6}$ & $\mathbf{1 9 9 7}$ & $\mathbf{1 9 9 8}$ & $\mathbf{1 9 9 9}$ & $\mathbf{2 0 0 0}$ & $\mathbf{2 0 0 1}$ & $\mathbf{2 0 0 2}$ & $\mathbf{2 0 0 3}$ & $\mathbf{2 0 0 4}$ & $\mathbf{2 0 0 5}$ & $\mathbf{2 0 0 6}$ & $\mathbf{2 0 0 7}$ \\
\hline 1. Disneyland Resort Paris & 10.7 & 11.7 & 12.6 & 12.5 & 12.5 & 12.0 & 12.2 & 10.3 & 10.2 & 10.2 & 10.2 & 10.6 & 12.0 \\
\hline 2. Blackpool Pleasure Beach & 7.2 & 7.5 & 7.8 & 6.6 & 6.9 & 6.8 & 6.5 & 6.4 & 6.2 & 6.2 & 6.0 & 6.0 & 5.5 \\
\hline 3. Tivoli Gardens & 2.4 & 3.1 & 3.2 & 2.8 & 3.1 & 3.9 & 3.9 & 3.8 & 3.3 & 4.2 & 4.1 & 4.4 & 4.1 \\
\hline 4. Europa Park & 2.5 & 2.5 & 2.7 & 2.7 & 3.0 & 3.0 & 3.1 & 3.3 & 3.3 & 33 & 3.9 & 4.0 & 4.0 \\
\hline 5. Port Aventura & 2.7 & 3.0 & 3.0 & 2.7 & 3.0 & 3.1 & 3.3 & 3.3 & 3.1 & 3.1 & 3.3 & 3.5 & 3.7 \\
\hline 6. Efteling & 2.7 & 3.0 & 3.0 & 2.7 & 3.0 & 2.9 & 3.1 & 3.0 & 3.2 & 3.2 & 3.3 & 3.2 & 3.2 \\
\hline 7. Liseberg & 2.2 & 2.4 & 2.5 & 2.5 & 2.6 & 3.0 & 3.1 & 3.1 & 2.8 & 3.0 & 3.1 & 3.0 & 3.1 \\
\hline 8. Gardaland & 2.5 & 2.4 & 2.7 & 2.7 & 2.8 & 2.9 & 2.9 & 2.9 & 3.0 & 3.1 & 3.1 & 3.1 & 3.1 \\
\hline 9. Bakken & 2.4 & 2.1 & 2.1 & 2.0 & 2.3 & 2.5 & 2.5 & 2.8 & 2.7 & 2.5 & 2.6 & 2.7 & 2.7 \\
\hline 10. Alton Towers* & 2.7 & 2.7 & 2.7 & 2.5 & 2.8 & 2.4 & 2.3 & 2.5 & 2.5 & 2.4 & 2.4 & 2.4 & 2.4 \\
\hline
\end{tabular}

* Since 2007 Walt Disney Studios (Marne-La-Vallée) is number 10 with 2.5 million visitors. Alton Towers is number 11

Source: P. De Groote, based on TEA/ERA reports

World Resort that contains theme parks, hotels, dining, entertainment and sports complex, conference centers, water parks and other leisure facilities. It also manages Disney Cruise Line (cf. the Disney Magic was the first ship, 1998), Disneyland Resort Paris (1992), and Hong Kong Disneyland (2005) and Tokyo Disney Resort (1983). The corporation's Studio Entertainment sector produces, purchases, and allocates animated action pictures, musical recordings, home entertainment, videoon-demand, pay television, and free television markets. Disney Company distributes its products (i.e. books and magazines, computer software and video games) through Disney Stores (esp. in North America and Europe) and www. DisneyShopping.com.

\subsection{History of the company}

Walt Disney, and his legacy, especially given that he was born on 5 December 1901, just as the 20th century was beginning while it would be several decades before he would have a significant impact on the world, his contribution would eventually have a lasting impression in the hearts and minds of millions. The Walt Disney Company started on 16 October 1923 in Burbank as the Disney Brothers Cartoon Studio, a joint venture of Walt Disney and his brother, Roy. In 1926 the company had created two movies and bought a studio in Hollywood, California. Difficulties in distribution rights nearly went down Walt and his company, but the design of Mickey Mouse (1928) and Donald Duck saved a dropping boat. The ensuring years would bring with them merchandise licensing, full-length animated features like Snow White and the Seven Dwarfs (1937) and Pinocchio, television programs (like The Mickey Mouse Club since 1955), live-action movies, and, of course, one of Walt's most ambitions projects, a theme park called Disneyland. (D. Smith, S. Clark, p.21-27)

In 1955 opened the first Disney theme park, Disneyland in Anaheim. Disney maintained its rise in popularity, and

Table 6. Comparison of World's Disneyland Resorts

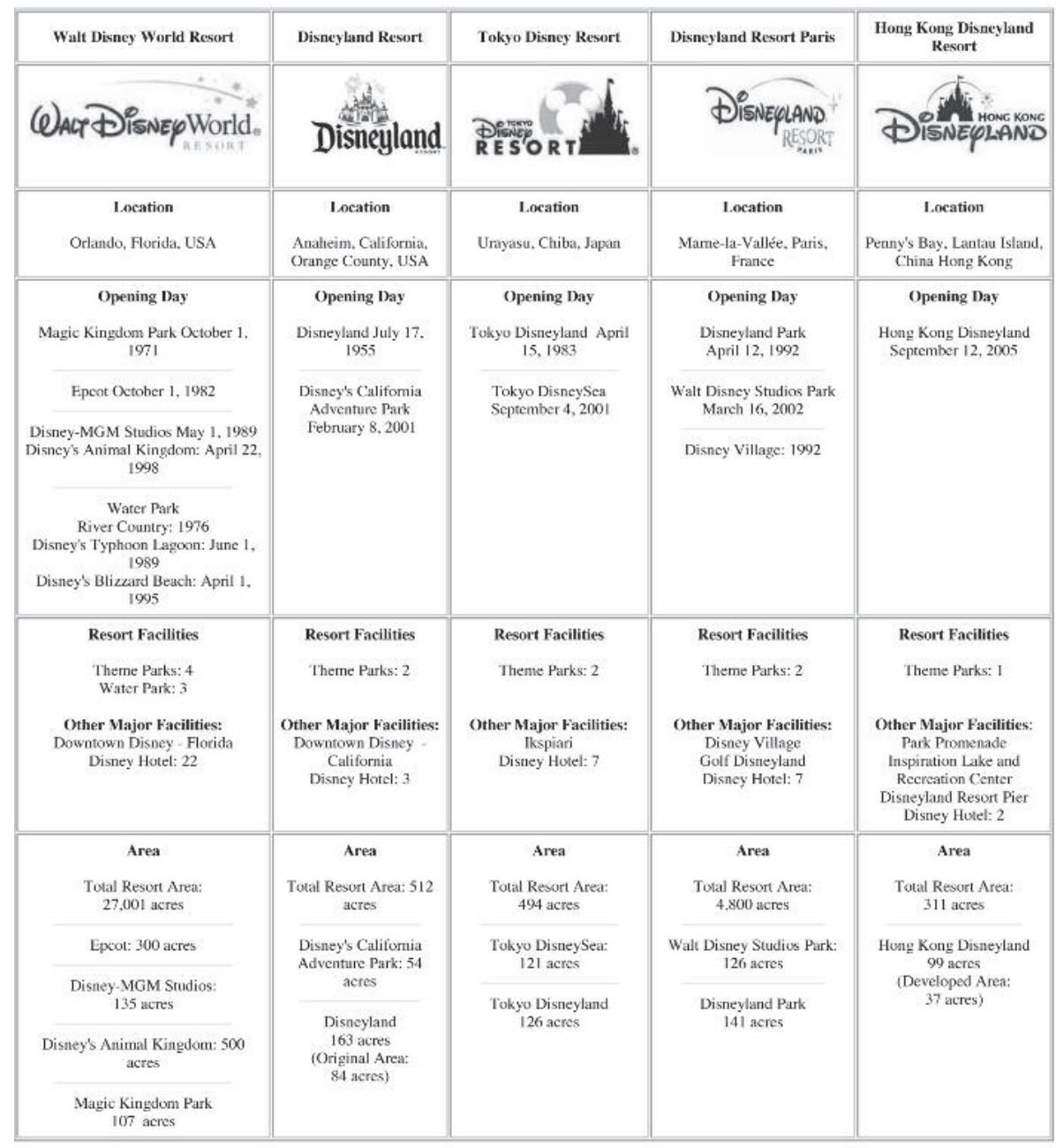

Source: www.skyscrapers.c 
stayed alive even after the death of its founder in 1966. His brother Roy took over control at that time, and then was succeeded by a management team in 1971. In 1983, Disney went international with the opening of Tokyo Disneyland. (www.disneyworldtrivia.com)

In the past few decades, Disney has went into a wider market, starting The Disney Channel on cable and creating subdivisions like Touchstone Pictures to make films other than the usual family-oriented fare, achieving a firmer balance on a broader series. In the 1970s and 1980s, the company experienced from takeover efforts, but got well thanks to successful team, leading Disney to continue its tradition of brilliance into a new century.

Walt Disney is now an expanded entertainment company, working in 4 business segments: media networks, studio entertainment, parks \& resorts, and customer products. The company got recently increasing net profits (esp. in 2007-8). Table 6 compares Disneyland Resorts in the USA, Paris, Hong Kong and Japan.

\subsection{SWOT Analysis}

The Disney Company (table 7) faces domestic weaknesses and strengths, which can to a certain level be controlled. The outside forces like opportunity and threats are more complex to manage, and Disney has to adopt and take advantage to those forces.

Disney's major strength is in its resources, practice in the entertainment business and its low-cost strategy. Moreover, the company evidently has expanded a very strong and well known brand name over 80 years. The company has also been able to spread its operations and products to evade against declining transactions in product lines. In recent years it has redirected into Film, Home Video, products, Radio and Television and in Theme Parks. It has also successfully worldwide diversified its business from USA to Japan and Europe. The main strengths in domestic resources refer to human resources and financial solidity. Employees in the Disney studios appear to be very innovative and in recent years they have created several productions. A corporation without new inspirations has a trouble in today's aggressive business environment. The low-cost company's strategy is an advantage for them. The company can manage costs, and still make quality goods and services. Financial risks have been reduced by sharing initial investment costs with the highest number of outside participants.

Disney's main weaknesses are: very large work force, frequent change in top-management, and high operating costs. The corporation mainly manages in the USA and has worldwide 137,000 employers in 2008 (cf. 60,000 in 1991). This fact shows potential communication difficulties, and a high administration level within the Disney Company. By expanding into more sectors and niches, the company's work force will rise even bigger, and the managerial structure has to be able to hold a growth of the work force. The fact that the company very often changes its corporate officers makes the company structure even more complex. There are many positive things that come with changes, but modification is also connected with struggle, and big expenditures. Great operating costs are typically direct results of a large work force and a big number of fixed assets. For example, ticket prices should not be able to go above $33 \$$ for entry to Disney's theme park. Visitors are not prepared to spend more money than that. As a result, operating costs should be strongly observed to match the price that customers are willing to pay for the goods and services offered.

External opportunities must be recognised, examined, and responded to in a very early phase. The Disney Company is facing numerous external opportunities like positive government attitudes towards its operations, barriers of entry, large group of loyal visitors and the entertainment industry itself. Official and governmental forces are usually recognised as being negative external features to a company. Paradoxically, in Disney's case, the French government donated significantly in the Euro Disney plan with over USD 1.2 billion, built transport facilities, and gave Disney tax relief's on expenditure of goods sold accounts. Also, since the difficulties of entry into the greatly specialised business in which Disney is operating, competition will find it complicated to infiltrate the company's highly
- Over saturated markets,

- Increasing number of serious and actively operating competitors, which address their offer to the same segment of clients (e.g. Six Flags)

- Bigger elasticity of competitors in adapting to particular segment of clients thanks to the smaller volume of sales,

- Increasingly competitors offer, which is perceived by clients and retailers as a wider and better available, 
diversified product and service mix. In addition, huge initial capital investments are needed to come into the business.

Main threats to the Disney Company are over saturated markets and foreign competition. As the supply of services and products in the entertainment business was starting to saturate the markets, competition is more powerful, and the most dominant companies survived. Some of its functions, such as the Network-television division may not be able to handle the force from the Cable-giants like Turner Broadcasting Systems (TBS).

\section{Euro Disney Resort in Paris}

The Euro Disney SCA Group's major action is the operation of the Disney Resort in Paris (figure 5). It was built in the New Town Marne-La-Vallée (32 km east of Paris) by 1,700 companies and 10,000 workers from 2 August 1988 until the official opening on 12 April 1992. The features contain the Disney land Paris Theme Park, several theme hotels, symposium facilities, the Disney Village amusement center including 15 cinemas, 3D adventure screens and golf lessons. The Group also controls the real estate growth and expansion of the related infrastructure of the assets; they possesses Disneyland Park, Hotel Disneyland, Walt Disney Studios Park and Ranch Davy Crockett. (www.eurodisney.com)

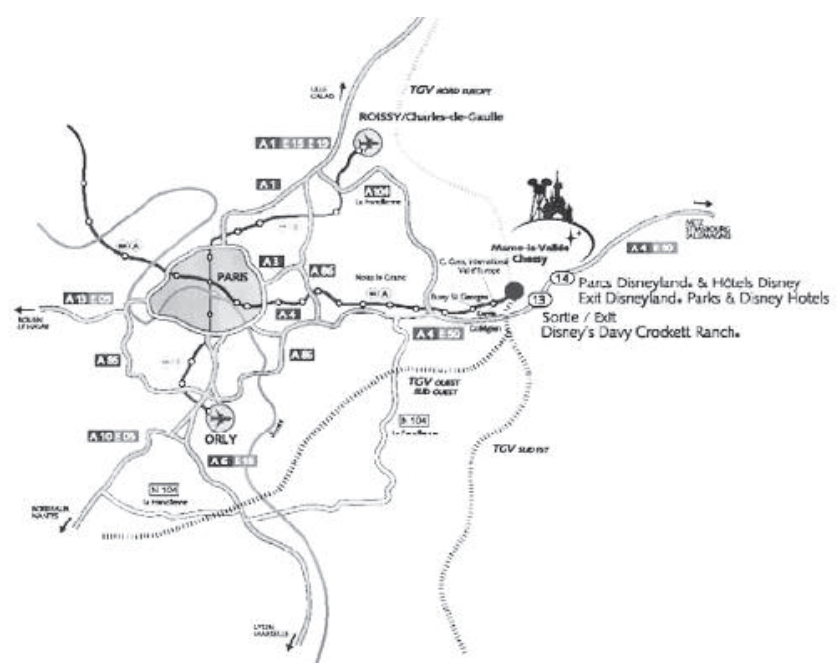

Figure 5. Location of Euro Disneyland Resort in Marne-la-Vallée Source: www.eurodisney.com

\subsection{Historical background}

The plan of a European amusement resort and park complex had been developing within Disney since the early 1980s. In 1981, the company began a worldwide bidding procedure for situating Euro Disney, originally involving Germany, Spain, France and others. With continued success of the three existing parks, the promise of a new European Union was too much to resist. The most important detail was the location. The choice was to be made between Spain and France. Despite worse weather conditions and less generous offer from
France, in 1985 the decision has been made. Two years later, Michael Eisner and Jacques Chirac, signed a contract for the building of a Disney theme park at Marne-La-Vallée with Robert Fitzpatrick as the president of Euro Disneyland. Next to the proximity of Paris (one of the world's tourism capitals) the central location with large potential visitors from Germany and Great Britain (cf. The Chunnel) was another decision reason.

Despite over 7 years of planning and doing research, Euro Disney quickly developed in one of the most costly mistakes in company history. In the first 2 years of operation, Euro Disney lost close to 1.03 billion $\$$. They were close to go bankrupt. Initial failure can be connected with the? European Recession. Just as Euro Disney opened, Europe was in the middle of an economic slump. Disney felt that they could overcome this issue; however, Europeans had little spending power at that time (1992-4) and the decline in France's GDP resulted in a decrease of disposable income among the French population. Many other European countries were experiencing similar problems.

Furthermore Disney didn't expect the huge cultural differences between the Americans and the Europeans. The whole resort was planed along the identical principles as the original Disneyland in the USA. When they were opening the Disneyland in Tokyo, Japanese people were saying that they don't want being Japanese, but they came there to see America and for Disney. They wanted to know America. Disney thought that the Europeans would react in the same way. But they didn't. There were many differences in which French couldn't agree. Consequently, Euro Disney was not accepted between the European societies. The problem was also with the marketing policy. Euro Disney was promoted wrongly to the consumers. The resort was advertised in the American-style of "bigness and extravagance". Instead, Euro Disney should have concentrated on the emotional aspect, marketing that visitors would have a unique, unusual experience they would not forget. (www.eurodisney.com)

\subsection{Financial problems}

Many additional domestic and external factors gave the opening failure of Euro Disney. Contact gaps, increasing interest rates, decrease in the real estate market, operational mistakes, and high labor costs all gave the 1 billion \$ total loss in 1992 and 1993. Fortunately for Disney, many of these issues were accurate. By 1995, Euro Disney was able to make a profit of 15.6 million \$. Euro Disney SCA. is a Société en Commandite par Actions. Under French regulation, this structure establishes an obvious characteristic between the Gérant who is responsible for working the Company and the management board, which administers the management of the Company.

Disney Company is Euro Disney's largest shareholder (figure 6), with $39,8 \%$ of its stock. $10 \%$ of shares belong to Prince Alwaleed (Nephew of Saudi King Abdullah, world's wealthiest Muslim businessman, Saudi Arabia) and his family. Other shareholders possess $50,2 \%$ of its stocks. Since 1 November 2005, Euro Disney SCA share are only issued on the Paris Stock Exchange. (www.eurodisney.com) 

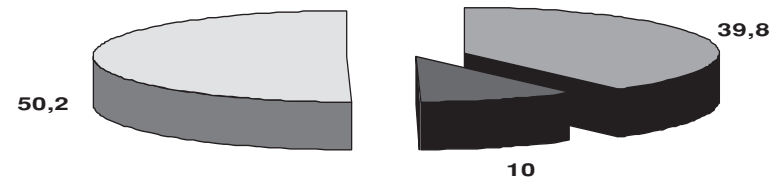

$\square$ The Walt Disney Company $\square$ Prince Alwaleed and his family $\square$ Other shareholders

Figure 6. Euro Disney - shareholder's structure

Source:www.eurodisney.com

Euro Disney Paris is one of Europe's top family vacation purposes. In 2004 park's attendance (figure 7) was equal to 12, 4 millions of visitors. But in 2005 this number decreased slightly by 12,3 million (1\%). During 2006, the company continued its development strategy planned to attract and keep theme parks' tourists and hotel guests, and started to see some first profits. Theme Parks attendance for fiscal year 2006 increased to 12,8 million. Euro Disney Paris has 49,000 direct and indirect jobs, including more than 13,000 employed at the Resort itself.

Theme Parks Attendance (in millions of visits)

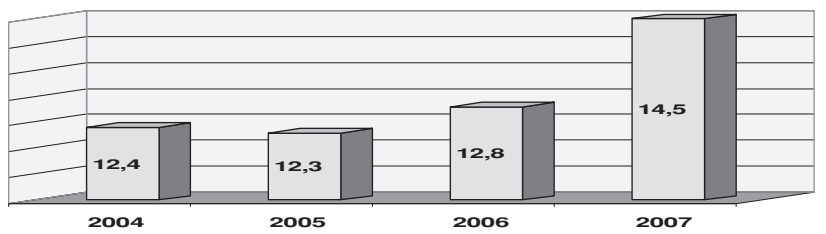

Figure 7. Theme Parks Attendance

Source: own calculation based on eurodisney.com
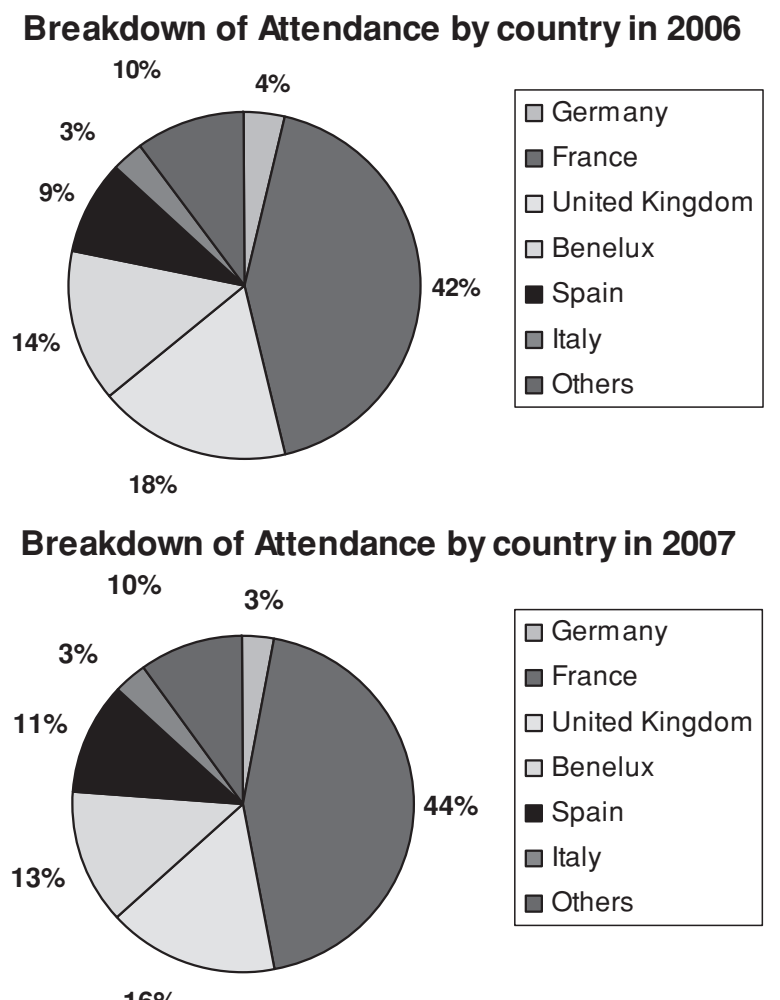

$16 \%$

Figure 8. Breakdown of Attendance by country

Source: own calculation based on eurodisney.comOnderkant formulier
In 2007 and 2008 records of 14.5 and 15.3 million of visitors were registered, and so it is the top-visited tourist attraction/destination of Europe. The increase in theme parks attendance primarily reflects growth in the French, Spanish and United Kingdom markets (figure 8). Euro Disney's strong figures were credited to increased guest expenditure and theme park attendance, partly balanced by upper operating costs. Increased visitor spending was due to higher expenditures for food, beverage and merchandise, higher average ticket prices and higher average daily room rates. In 2007 spending per guest was equal to $€ 45$ and spending per room $€ 197,9$ (figure 9).

\section{Theme Parks Spending per} (in euros, excl. VAT)
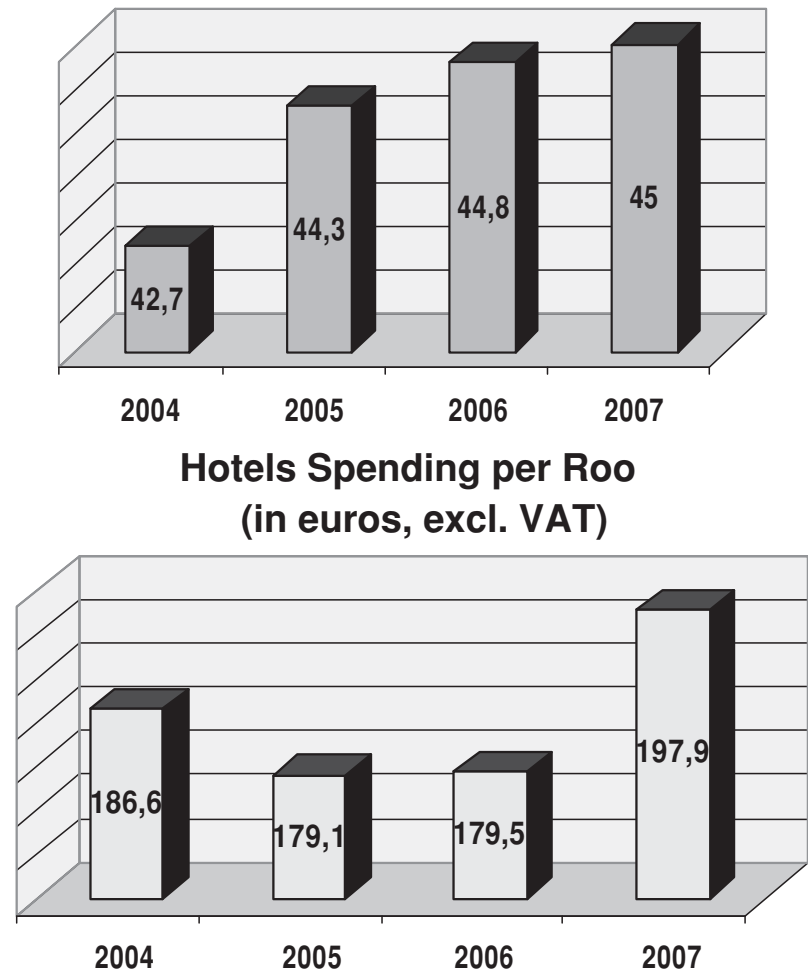

Figure 9. Theme Parks Spending per Guest Source: own calculation based on eurodisney.com

During 2007, the company celebrated the Resort's 15th anniversary, though continuing with its expansion strategy designed to increase both visitor volume and spending at the Resort by attractive products and services to best meet the visitors' needs and to take benefit of what management believes are significant opportunities to attract and keep visitors. The hotel occupancy rate improved by 5,8\%, compared to fiscal year 2006 to $89,3 \%$ in 2007 which was the result from an incremental 123,000 room nights compared to previous year 2006. This raise was also driven by more guests visiting from Spain, United Kingdom and France.

\subsection{Future and Conclusion}

As Disney walks into the new millennium, it is impossible to predict all changes and advances that will 
occur within the Company. While there are many plans for particular films, theme parks, attractions, television series, and other projects. No one can forecast precisely what the 21st C has in store for Disney, but one thing is sure: the Company is leading to meet the next hundred years by continuing and increasing upon its presence in all current areas of effort while reaching into some that have not yet even been considered.

Certainly, through the past 100 years several generations have been touched by Disney's characteristic brand of original magic world. Some may believes that the Disney Company has done all there is to do, but Walt's never-ending creative vision lives on within the animators, actors, imaginers, musicians, and other people world wide who are responsible for concreting the road to Disney's future. Just by looking at the plans stated for the first few years of this new millennium, one can see that the future at Disney is both exciting and filled with a character of fantastic originality. As Walt marked, "I only hope that we never lose sight of one thing- that it was all started by a mouse".

The Walt Disney Resort has come an extensive way from marshland to vacationland. Through some land purchases in the last twenty years, it now covers 30,500 acres. Its initial number of Cast Members has grown from 5,500 to 36,000. Attractions, Resorts, and even added theme parks are in expansion for years to come. The Vacation Kingdom of the World has considered and informed people young and old from all over the world (Tombs Dominic \& Quinn Brian, 2005 , p.255). Nowhere else on the globe can one meet a snow skiing alligator or robot transport pilots fly a magical pirate boat above the clouds, or ride a real vapor train through the Old West or discover a haunted hotel or stylish greenhouses, where growing systems platform the future of our planet's food supply. It promises every tourist that anything can really happen when they desire to be a star. And it is the realized vision of one man who believed that anyone can achieve what they set their brain to: Walt Disney.

\section{References}

\section{Books \& Guides:}

Clave A. (2007): The global theme park industry, CABI, Oxfordshire, $459 \mathrm{p}$.
De Groote P. (1999): Panorama op Toerisme, Garant, Leuven/Apeldoorn, $343 \mathrm{p}$.

De Groote P. (2006): België en Wereldtentoonstellingen: Quo Vadis?, FOD Economie, Brussel, 44 p.

Dunlop Beth (1996): Building a dream. The art of Disney architecture", Harry N. Abrams Inc., New York, 208 p.

Jafari J. (2000): Encyclopedia of Tourism, Routledge, London/New York, $683 \mathrm{p}$.

Knowles T., Diamantis D. \& El-Mourhabi J.B (2004(2): The Globalization of Tourism \& Hospitality, Thomson, London, 321 p.

Lanquar R.(1991): Les parcs de Loisirs, PUF, Paris, 127 p.

Lanquar R.(1992): L'empire Disney, PUF, Paris, 127 p.

Littaye A. \& Ghez D.(2002): Disneyland Paris. De l'esquisse à la création, Nouveau Millenaire Editions, Paris, 320 p.

Metz, T (2002): Pret! Leisure en landschap, NAi Uitgevers, Rotterdam, 288 p.

Smith D. \& Clark S. (2002(2): Disney. The first 100 years, Disney Editions, New York, $214 \mathrm{p}$.

THEA/ERA (2008): Theme Park Attraction Attendance Report 2007, Burbank, 16 p. (yearly edition)

Tombs D. \& Quinn B. (2005): Columbus tourist attractions \& events of the world", UP Group, Lithuania, -p.

Van Willigen R. (1999): Mouse Entertainment. De geschiedenis van Walt Disney \& Company, Uitgeverij Sun/Kritak, Nijmegen/Leuven, $195 \mathrm{p}$.

Websites:

- http://corporate.disney.go.com/investors/index.html

- http://library.thinkquest.org/CR0210243/amusement\%20park\% 20history/amusementparkhistory.htm

- http://www.disneyworldtrivia.com/trivia/wdwhistory.php

- http://www.eurodisney.com/

- http://www.iaapa.org/

- http://www.islandnet.com/ kpolsson/disnehis/index.htm

- http://www.thefreedictionary.com/water+park

- http://www.themeit.com/attendance_report2006.pdf

- http://www.themeparkcity.com/itps/L_APhistory.htm

- http://www.ultimaterollercoaster.com/

- http://www.weitzlux.com/themeamusementparksattorney /history_4650.html

- http://www.skyscrapers.cn 